\title{
Does The E-Loyalty Increase As The Consumer's Access To The Internet Increases? An Empirical Study In Turkey
}

\author{
Naci BÜYÜKDAĞ \\ Akdeniz University \\ Faculty of Applied Sciences \\ Department of Marketing \\ Antalya, Turkey \\ orcid.org/0000-0002-9836-5942 \\ nbuyukdag@akdeniz.edu.tr
}

\author{
Olgun KİTAPCI \\ Akdeniz University \\ Faculty of Applied Sciences \\ Department of Marketing \\ Antalya, Turkey \\ orcid.org/0000-0002-5316-985X \\ okitapci@akdeniz.edu.tr
}

\begin{abstract}
The purpose of the study is to investigate whether the level of the Internet experience has a moderating effect on the relationship between e-satisfaction and eloyalty. Because according to the literature, the moderator effect of internet usage level has not been investigated in terms of the relationship between e-satisfaction and eloyalty. Therefore, there is a gap in the literature and this study aims to fill it. Multivariate methods were applied in this study. The level of the Internet experience has been the moderator effect on the relationship between e-satisfaction and e-loyalty. Consumers with low the Internet experience were found to show more e-loyalty than those who had high the Internet experience. As the internet usage increases competition, it is suggested that e-commerce companies should be differentiated from other competitors through e-trust, branding of the web site, use of social media communication channels and participation in social responsibility projects.
\end{abstract}

Keywords: E-satisfaction, E-loyalty, Moderation, The Internet Experience, Statistical Power Analysis

\section{Introduction}

E-commerce is a big sector that is constantly growing (Nielsen Report, August 2014, p.2). E-commerce transaction volume doubled from 2002 to 2012 (UNCTAD, 2015, p.12). As a result of e-commerce's low cost, fast access, flexibility and access to markets, many companies need to adapt their traditional structures to e-commerce (Yilmaz et. al., 2016) and have started to take part in the e-commerce sector. Yet, there are challenges in the e-commerce industry and one of them is a hugely competitive environment waiting for companies because all competitors are only a click away. (Lee et al., 2009, p.7848). One of the most important elements to be able to get over of the competitive environment and to be successful is to analyze consumer behavior (Hernández et al., 2010, p.964). The most important behaviors are e-satisfaction and eloyalty. The reason for this is that they are one of the most important factors for success in the online environment (Shaw and Lin, 2006, p.384). Many studies have been carried 
out in the literature to explain the relation between e-satisfaction and e-loyalty (Anderson ve Srinivasan, 2003; Christodoulides ve Michaelidou, 2010). This relationship has been examined in this study. A second element that promotes ecommerce is the widespread use of the Internet. Because of the use of the Internet, which forms the basis of e-commerce, E-commerce is also continuously increasing (Kemp, 2016). For example, by 2015, the number of the Internet users has increased by $10 \%$, reaching 3,419 billion people and this number corresponds to approximately $46 \%$ of the world population (Kemp, 2016). In the e-commerce sector, with the increasing use of the Internet, consumers who use the Internet to varying degrees have emerged. The aim of the study is to investigate how the level of internet use of consumers affects the relationship between e-satisfaction and e-loyalty. In other words, the main purpose of this study is to analyze the relationship between e-satisfaction and e-loyalty, by testing the moderating effect of the Internet experience. Because there is a gap in the literature on this subject. This study aims to fill the gap in the literature. Thus, it also aims to suggest administrative and practical implications to e-commerce companies in the globalizing world. In the first part of the study, the literature on e-satisfaction and eloyalty dimensions was searched. In the second part of the study, the moderator effect of the Internet experience variable was investigated on the relationship between esatisfaction and e-loyalty.

\section{Literature Review}

\section{E-satisfaction and E-loyalty}

The concept of customer satisfaction is among the basic concepts in the field of marketing and has a key role in satisfying the needs of the customer (Chang and Wang, 2011, p.337). In addition, the satisfied customer is also eager to pay more to get the product or service they need (Casidy and Wymer, 2016, p.190). So, customer satisfaction provides the competitive advantage and affects the performance of companies in the globalised environment (Casidy and Wymer, 2016, p.189). As a result, companies are trying to increase the satisfaction levels of their customers. When these efforts take place in the electronic environment, the concept of satisfaction leaves its place to the concept of e-satisfaction. E-satisfaction is defined as "the contentment of the customer with respect to his or her prior purchasing experience with a given electronic commerce firm" in the study conducted by Anderson and Srinivasan in 2003 (p.125). In other words, e-satisfaction is defined as the difference between the expectations and the results of shopping on the website (Forgas-Coll et al., 2013, p.259; Forgas et al., 2012, p.43). E-satisfaction is not only the performance indicator of the firm (Evanschitzky et al., 2004, p.239), but also the antecedent of e-loyalty concept (Chiou, 2004; Cyr et al. 2008; Evanschitzky et al., 2004, p.239; Anderson and Srinivasan, 2003, p.124). E-loyalty is defined as " the customer's favorable attitude toward an electronic business resulting in repeat buying behavior " in the study conducted by Anderson and Srinivasan in 2003 (p.125). According to Safa and Ismail (2013), e-loyalty is the commitment and positive attitude resulting in the customer's repurchase for websites (p.559). As can be understood from the definition, there is a positive relationship between the e- satisfaction and e-loyalty (Anderson ve Srinivasan, 2003; Christodoulides ve Michaelidou, 2010; Dharmesti ve Nugroho, 2013; Rodgers et al., 2005, p.316). In terms of this relationship, according to Anderson, satisfied customers are more loyal than those who are not satisfied (Anderson and Srinivasan, 2003). As a result, the following hypothesis can be established. 
$\mathrm{H}_{1}$ : The e-satisfaction has a positive impact on e-loyalty.

Customer loyalty is one of the most important keys to success regardless of whether it is online or offline, and it is a priority to know the determinants of e-loyalty in terms of marketing science (Shaw and Lin, 2006, p.384). Because loyal customers tend to buy more goods/services, are willing to pay more for the product, talk more about the products, adopt and advocate the products, and are more likely to become profitable customers (Harris and Goode, 2004, p.139; Han et al., 2011, p.1008). Therefore, one of the primary goals of the companies is to transform the satisfied customer into a loyal customer. But this transformation is not an easy phenomenon because there are too many factors that affect the relationship. In other words, although customer satisfaction is a necessary variable for loyalty, it is not enough (Chang and Chen, 2008, p.2928). Because there are individual and firm-driven factors that affect the relationship between e-loyalty and e-satisfaction (Anderson ve Srinivasan, 2003; Bai et al., 2008, p.394). According to Shankar (2003), the ease of access to information and the frequency of use are some of the factors that affect the relationship between esatisfaction and e-loyalty (p.155). The most important tool that can be used to access information and make e-shopping is the Internet.

\section{The Internet Experience}

The Internet experience is defined as a general experience of using the browser such as the Internet Explorer, to reach World Wide Web (www) pages (Chang and Chen, 2008, p.2933). The Internet experience is also a variable that can be used as a moderator to understand the perceptions, attitudes, and behaviors of customers in online medium (Chang and Chen, 2008, p.2933; Nysveen and Pedersen, 2004) because customers who have experience on the Internet are making online purchases (Blake et al.2003, p. 156; Varma Citrin et al. 2000,p. 294 ). Since e-satisfaction and e-loyalty attitudes emerged as a result of shopping on the Internet, it can be concluded that the Internet experience level moderate the relationship between e-satisfaction and e-loyalty. As a result, the following hypothesis can be established.

$\mathrm{H}_{2}$ : The relationship between e-satisfaction and e-loyalty is moderated by the Internet experience.

\section{Methodology}

In the study, convenience sample method was used and a web-based survey was prepared. Online survey questionnaire increases the speed of the research and provides time and cost advantages (Malhotra, 2007, pp.356). The online survey questionnaire was sent to different mailing lists and shared on social media channels. The questionnaire used in the research consists of two parts. In the first part of the online survey questionnaire, the demographic characteristics of the participants were measured. The second part of the online survey questionnaire, e-satisfaction and eloyalty attitudes of consumers buying goods/services from e-commerce companies were measured. The online survey questionnaire was designed as "It is necessary to answer every question" and was generated via google drive. E-satisfaction and e-loyalty scales developed by Anderson and Srinivasan in 2003 were used in the research. From these attitude scales, e-satisfaction consists of 6 items and e-loyalty consists of 7 items and all of the attitude scale are unidimensional.http://tureng.com/tr/turkceingilizce/unidimensional The average time that consumers spend on the Internet is measured by the Internet experience. 
The target volume of the study consists of consumers who shop online. The data were collected between April 26 and May 18, 2016, and just 288 online questionnaires were found to be usable. When the target population number is not known, the sample is computed with $n=\left(Z^{2} *\left(P^{*} Q\right)\right) / E^{2}$ (Nakip, 2013, pp.306). With this Formula ( $\mathrm{p}=0,5$, $\mathrm{q}=0,5, \mathrm{Z}=1,96$ and $\mathrm{E}=0,05)$, the number of samples for the unknown population is calculated as 384 . Despite the fact that 384 samples are sufficient for the population that is unknown, 288 samples have been reached in this study due to time and cost constraints. In order to overcome this problem, power analysis developed by Cohen in 1962 was used. According to Cohen, if any of the statistical power, alpha, sample size, and effect sizes are known, others can be obtained depending on them (Keskin, 2012). However, since there is no study of the effect size in the e-commerce literature, the minimum number of samples to be used can not be determined in advance. Therefore, the accessible sample was used, but then power analysis was performed using the analysis results. For this power analysis, $G^{*}$ Power 3.1.9.2 program developed by Cohen was used. The statistical power analysis results of the analysis results are also shown in Figure 1.

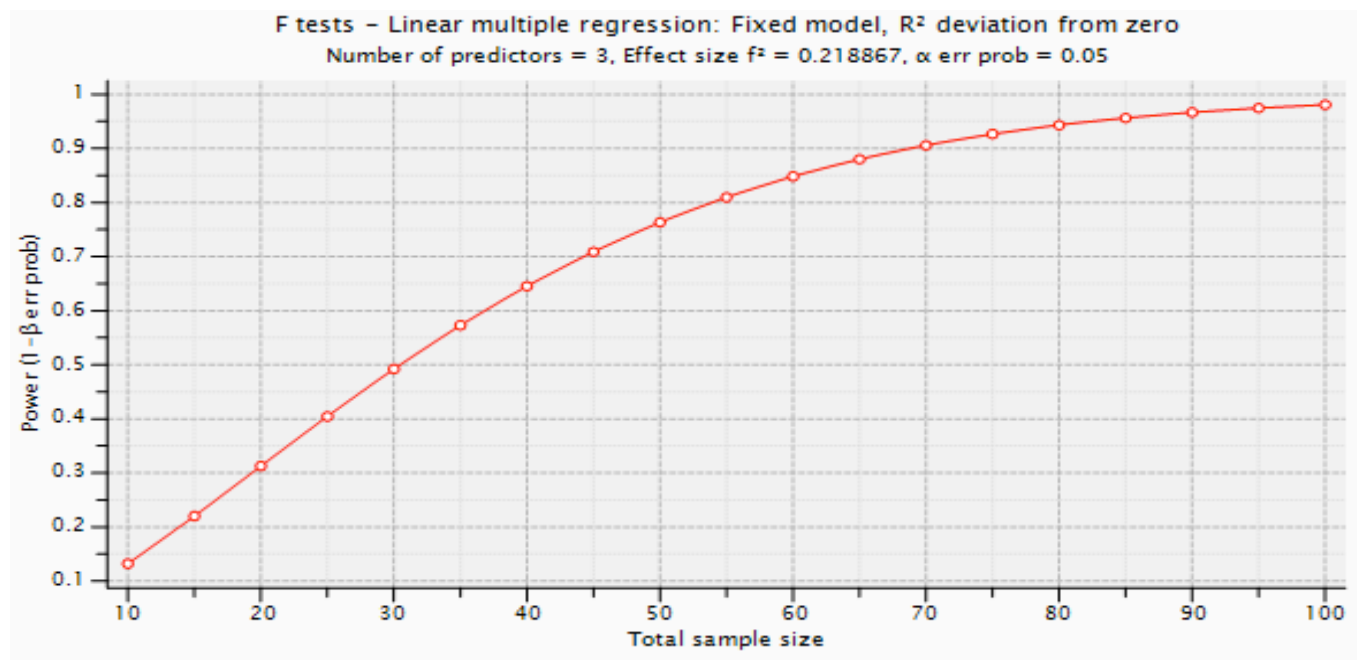

Figure 1: Statistical Power Analysis Results

According to the results of the analysis, a sample number of 100 and above is sufficient and the study is statistically very strong. In other words, the findings are very likely to be true. The online questionnaire return rate was approximately $10,8 \%$. Demographic characteristics of the respondents are shown in table 1.

Table 1: Demographics of Respondents

\begin{tabular}{lll}
\hline & Frequency & \% \\
\hline Gender & & \\
Female & 155 & 47.7 \\
Male & 170 & 52.3 \\
Total & 325 & 100 \\
\hline Age & & \\
$18-24$ & 47 & 14.6 \\
$25-34$ & 158 & 49.1 \\
$35-44$ & 84 & 26.1 \\
Above 45 & 33 & 10.2 \\
Total & 322 & 100 \\
\hline
\end{tabular}




\begin{tabular}{lll}
\hline Education & 34 & \\
Pre-University & 90 & 10.5 \\
Bachelor's Degree & 201 & 27.7 \\
Post Graduate & 325 & 61.8 \\
Total & & 100 \\
\hline Job & 254 & 78.2 \\
Official & 30 & 9.2 \\
Private Sector & 36 & 11.1 \\
Student & 320 & 100 \\
Total & & \\
\hline Marital Status & 186 & 57.2 \\
Married & 139 & 42.8 \\
Single & 325 & 100 \\
Total & & \\
\hline Income & 34 & 10.5 \\
Under 1000 TL & 21 & 6.5 \\
1000-1999 TL & 37 & 11.4 \\
2000-2999 TL & 233 & 71.7 \\
Above 3000 TL & 325 & 100 \\
Total & 26 & 8 \\
\hline Shopping Frequency from the Internet & 59 & 18.2 \\
Once a week or more & 75 & 23.1 \\
Once in every 2-3 weeks & 165 & 50.8 \\
Once a Month & 325 & 100 \\
Several times a year & & \\
Total & & 100.5 \\
\hline Online payment options & 34 & \\
Payment at the door or money order & 290 & \\
Credit card, etc. & 324 & \\
Total & & \\
\hline & & \\
\hline & & \\
\hline
\end{tabular}

\section{Data Analysis}

In the data analysis process, reliability analysis, factor analysis, cluster analysis and multiple regression analysis were used. Reliability analysis of these methods is an evaluation of the degree of consistency between multiple measurements of a variable and the most widely used indicator is Cronbach $\alpha$ and the generally accepted Cronbach $\alpha$ 's minimum value is 0.70 (Hair et. al., 2014, pp.123). Factor analysis plays a unique role in the implementation of other multivariate techniques. It is the first method that should be used when multivariate analysis techniques are considered and is carried out to create new and fewer variables that represent a number of variables that correlate with each other (Hair et. al., 2014, pp.92). Although there are many methods for factor analysis, "principal components analysis" is preferred in this study because it is one of the most frequently used factoring methods (Çokluk et. al., 2014, pp.198). According to Hair et al. (2014), a number of observations required for factor analysis should be 100 or larger. The number of data used in the study is sufficient for the analysis. Bartlett's test of sphericity tests whether there is a significant correlation among at some of the items of the same dimension and the value of p should be less than 0.05 (Hair et. al., 2014, pp.102). If the value of Kaiser-Meyer-Olkin (KMO) value is higher than 0.60 , the 
number of sample size is sufficient. According to Hair et al. (2014), the lowest factor loading value should be 0.30 when the sample size is between 250 and 350 . In this study, Promax rotation method from oblique rotations is preferred because oblique rotations allow correlated factors instead of the fact that the rotated factors are independent of each other (Hair et. al., 2014, pp.114). Under these assumptions, principal components analysis's results are shown in table 2 .

Table 2: Principal Components Analysis's Results

\begin{tabular}{|c|c|c|c|}
\hline Dimensions and Variables & $\boldsymbol{\mu}$ & $\sigma$ & $\begin{array}{l}\text { Factor } \\
\text { Loading }\end{array}$ \\
\hline \multicolumn{4}{|l|}{ E-Satisfaction } \\
\hline $\begin{array}{l}\text { I am satisfied with my decision to purchase from this Web } \\
\text { site. }\end{array}$ & 5.46 & .954 & .539 \\
\hline $\begin{array}{l}\text { If I had to purchase again. I would feel differently about } \\
\text { buying from this Web site. }\end{array}$ & 4.54 & 1.462 & ----- \\
\hline My choice to purchase from this Web site was a wise one. & 5.34 & 1.150 & 654 \\
\hline $\begin{array}{l}\text { I feel badly regarding my decision to buy from this Web } \\
\text { site.a }\end{array}$ & 5.28 & 1.312 & .839 \\
\hline I think I did the right thing by buying from this Web site. & 5.38 & 1.142 & .671 \\
\hline I am unhappy that I purchased from this Web site.a & 5.52 & 1.280 & .949 \\
\hline Cronbach $\alpha$ & & .833 & \\
\hline Eigenvalue & & 5.693 & \\
\hline$\%$ of Variance Explained & & 47.442 & \\
\hline \multicolumn{4}{|l|}{ E-Loyalty } \\
\hline I seldom consider switching to another Web site. & 4.27 & 1.598 & 664 \\
\hline $\begin{array}{l}\text { As long as the present service continues. I doubt that I } \\
\text { would switch Web sites. }\end{array}$ & 4.70 & 1.616 & .730 \\
\hline $\begin{array}{l}\text { I try to use the Web site whenever I need to make a } \\
\text { purchase. }\end{array}$ & 5.03 & 1.456 & .783 \\
\hline $\begin{array}{l}\text { When I need to make a purchase. this Web site is my first } \\
\text { choice. }\end{array}$ & 5.17 & 1.387 & .755 \\
\hline I like using this Web site. & 5.36 & 1.177 & .593 \\
\hline To set his site is the best retail Web site to do business with. & 4.83 & 1.352 & .829 \\
\hline I believe that this is my favourite retail Web site. & 4.96 & 1.337 & .865 \\
\hline Cronbach $\alpha$ & & .861 & \\
\hline Eigenvalue & & 1.686 & \\
\hline$\%$ of Variance Explained & & 14.048 & \\
\hline Total Variance Explained & & 61.491 & \\
\hline Kaiser-Meyer-Olkin (KMO) & & .889 & \\
\hline Bartlett's test of sphericity & $\chi^{2}=2$ & 7.609 an & $\mathrm{p}=0.000$ \\
\hline
\end{tabular}

In the light of principal components analysis's results, it is seen that all assumptions are provided in the study. The Cronbach's alpha coefficients of esatisfaction and e-loyalty dimensions are respectively 0.833 and 0.861 and all dimensions are reliable. Discriminant and convergent validity are also provided. After the principal components analysis, the second applied method is cluster analysis. 
Cluster analysis is used to group objects based on the characteristics they possess (Hair et al., 2014, pp. 418). The purpose of using this method in the study is to sort into categories the daily average the Internet experience that was collected as continuous data whose mean is 4.13 and the standard deviation is 1.983 . The method of two-step cluster analysis (TSCA), developed by Chiu et al. (2001) and designed to employ very large data sets, is preferred as it is just one that enables the quantitative variables (Michailidou et al., 2009, pp.166). The results of the cluster analysis for this continuous data are shown in Figure 2 and in Table 3.

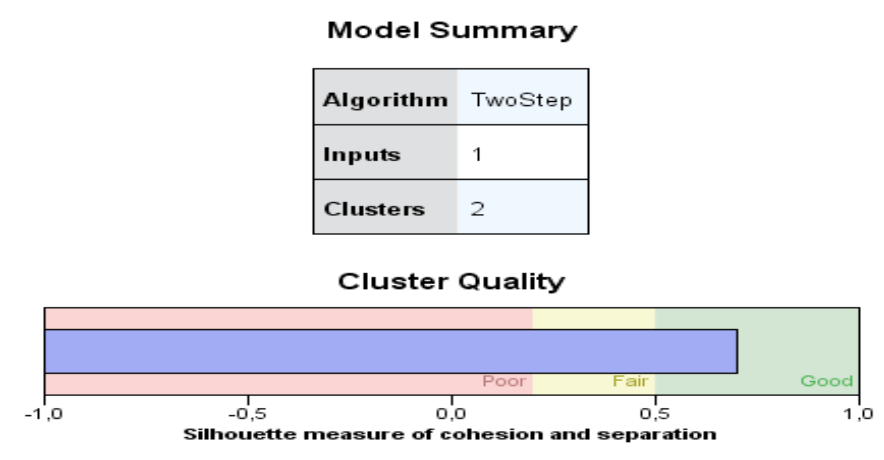

Figure 2: The silhouette measure of the clustering solution

Table 3: Two-step Cluster Analysis Results

\begin{tabular}{lccc}
\hline Dimension & N & $\begin{array}{c}\text { Mean of The } \\
\text { Internet Usage }\end{array}$ & $\begin{array}{c}\text { Percentage Usage of } \\
\text { The Internet }\end{array}$ \\
\hline High Usage of The Internet & 160 & 5.60 & 55.6 \\
Low Usage of The Internet & 128 & 2.29 & 44.4 \\
Total & 288 & & 100 \\
\hline
\end{tabular}

Note: Average silhouette measure of cohesion and separation $=0.7$

As a result of the two-step cluster analysis, it was found that $55.6 \%$ of the participants exhibited high usage while $44.4 \%$ displayed low usage. The silhouette measure of cohesion and separation, which is a measure of the goodness of the clustering solution, is an index that can take any value between -1 and +1 , and it reflects the efficacy of a cluster solution in maximizing within-cluster homogeneity and maximizing between cluster heterogeneity (Tsiptis \& Chorianopoulos, 2009, p. 99-100; Lamont and Jenkins, 2013, p.399-400). An average silhouette coefficient of 1 indicates that clustering is performed perfectly and coefficient of 0.5 indicates a "reasonable solution," and less than 0.2 indicates a "problematic solution" (Tsiptis \& Chorianopoulos, 2009, p. 99-100; Lamont and Jenkins, 2013, p.399-400). In this study, the silhouette coefficient is 0.70 which indicates that the clustering analysis is performed correctly.

After the two-step cluster analysis, the third applied method is moderator analysis that was implemented via multiple regression methods. A moderator, which can occur either quantitatively or qualitatively, affects the strength or direction of the relationship between an independent variable and a dependent variable (Baron and Kenny, 1986, p.1174). Moderation analysis is causal models that suppose "when" or "for whom" or "under what circumstances" or "what types of people" a predictor variable most strongly (or weakly) causes a criterion variable (Baron and Kenny, 1986; 
Wu and Zumbo, 2008; Kraemer et al., 2001; Hayes and Rockwood, 2016, p.9). The correlation between the moderator variable and both the dependent and the independent variable must be checked before the moderator analysis is performed. According to the Baron and Kenny, the interaction term can be explained clearly if the moderator variable does not correlate with the independent variable and the dependent variable (Baron and Kenny, 1986, p.1174). However the interaction term can be highly correlated with the independent or moderator variable and results in high multicollinearity problem in the analysis process because the interaction term consists of the multiplied by the moderator variable and independent variable (Baron and Kenny, 1986; Wu and Zumbo, 2008; Kraemer et al., 2001; Hayes and Rockwood, 2016; Lindley and Walker, 1993). To overcome the multicollinearity problem, Centering which is used independent variable's and moderator variable's standardised values were applied (Lindley and Walker, 1993, p.277; Wu and Zumbo, 2008, p.381; Kim et al., 2001, 67-68; Hayes, 2013, p.277). In addition, centering does not change the significance of the moderation test, it only changes the regression coefficient. (Wu and Zumbo, 2008, p.381). The correlation for all variables is shown in table 4.

Table 4: The Correlation Matrix

\begin{tabular}{lccc}
\hline Kendall's Tau-b & E-Loyalty & E-Satisfaction & $\begin{array}{c}\text { The Usage of The } \\
\text { Internet }\end{array}$ \\
\hline E-Loyalty & 1 & $0.419^{* *}$ & -0.006 \\
E-Satisfaction & $0.419^{* *}$ & 1 & -0.063 \\
The Usage of The Internet & -0.006 & -0.063 & 1 \\
\hline
\end{tabular}

** Correlation is significant at the 0.01 level (2-tailed)

* Correlation is significant at the 0.05 level (2-tailed)

As a result, the usage of the Internet that is categorical data will be examined that moderate the relation of e-satisfaction and e-loyalty. This analytical model is shown in Figures 2 and Figures 3.

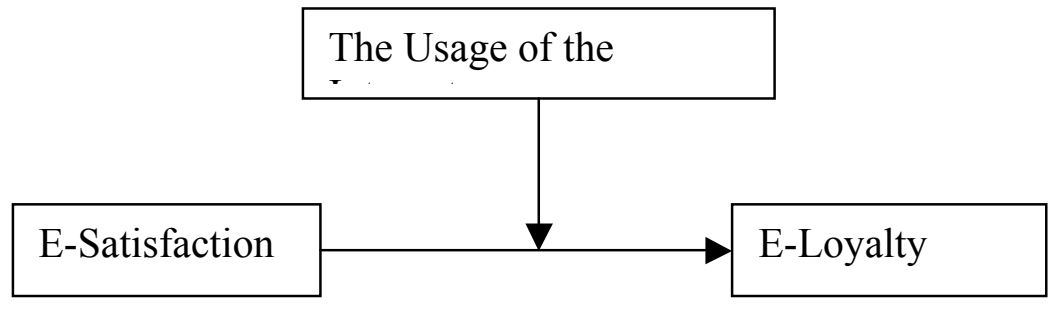

Figure 3: Diagram for Model

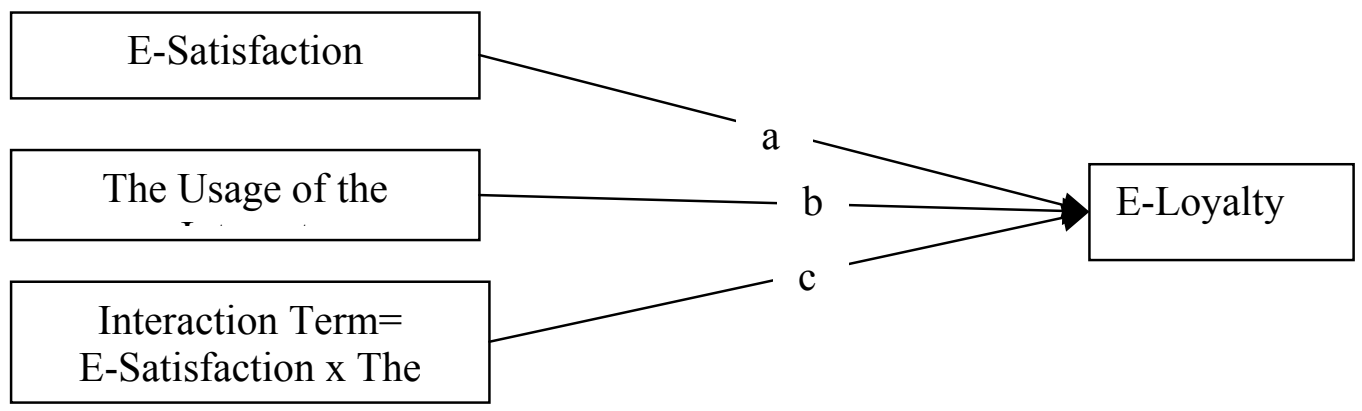

Figure 4: Path Diagram of the Moderation Model 
The mathematical representation of the moderator model is written as follows. E-Loyalty $=\mathrm{i}+\mathrm{a}^{*}$ E-satisfaction $+\mathrm{b}^{*}$ The Usage of The Internet $+\mathrm{c}^{*}$ Interaction Term, where $\mathrm{i}$ is the regression intercept, $\mathrm{a}$ is the regression coefficient for the independent variable, $\mathrm{b}$ is the regression coefficient for the moderator, and $\mathrm{c}$ is the regression coefficient for the interaction term which is the moderation effect $(\mathrm{Wu}$ and Zumbo, 2008, p.380).

According to Baron and Kenny (1986), regardless of whether the coefficients a and $b$ are significant, if the interaction coefficient $c$ is significant, then there is moderator effect. The hierarchical multiple regression methods were used for the moderator analysis, and the results of the analysis are shown in table 5.

Table 5 Hierarchical Regression Analysis of E-satisfaction, The Usage of The Internet and E-loyalty

\begin{tabular}{|c|c|c|c|c|c|c|}
\hline \multicolumn{7}{|c|}{ Dependent Variable: E-loyalty for Model 1} \\
\hline Independent Variables & $\mathbf{F}$ & $\begin{array}{l}\text { Unstandardized } \\
\text { Beta Coefficients }\end{array}$ & S.E. & $\mathbf{T}$ & $\mathbf{P}$ & VIF \\
\hline Constant & \multirow{3}{*}{$60.447 * *$} & $1.286^{* *}$ & 0.373 & 3.454 & $.001 * *$ & \multirow{3}{*}{1.006} \\
\hline E-satisfaction & & $0.304 * *$ & 0.06 & 10.988 & $.000 * *$ & \\
\hline $\begin{array}{l}\text { The Usage of The } \\
\text { Internet }\end{array}$ & & 0.045 & 0.107 & .422 & .673 & \\
\hline $\mathbf{R}^{2}=0.298$ & \multicolumn{2}{|c|}{ Adjusted $\mathbf{R}^{\mathbf{2}}=0.293$} & \multicolumn{4}{|c|}{ Durbin-Watson value $=2.155$} \\
\hline \multicolumn{7}{|l|}{$\Delta \mathbf{R}^{2}=0.298^{* *}$} \\
\hline \multicolumn{7}{|c|}{ Notes: *: $p<0.05$ and $* *: p<0.01$} \\
\hline
\end{tabular}

Dependent Variable: E-loyalty for Model 2

\begin{tabular}{|c|c|c|c|c|c|c|}
\hline Independent Variables & $\mathbf{F}$ & $\begin{array}{c}\text { Unstandardized } \\
\text { Beta Coefficients }\end{array}$ & S.E. & $\mathbf{T}$ & $\mathbf{P}$ & VIF \\
\hline Constant & \multirow{4}{*}{$42.022 * *$} & $1.315^{* *}$ & .371 & 3.546 & $.000 * *$ & \multirow{3}{*}{1.006} \\
\hline E-satisfaction & & $.652 * *$ & .059 & 10.984 & $.000 * *$ & \\
\hline $\begin{array}{l}\text { The Usage of The } \\
\text { Internet }\end{array}$ & & .043 & .107 & .406 & .685 & \\
\hline Moderator Effect & & $.107 *$ & .054 & 1.982 & $.048 *$ & 1.001 \\
\hline $\mathbf{R}^{2}=0.307$ & \multicolumn{2}{|c|}{ Adjusted $\mathbf{R}^{2}=0.300$} & \multicolumn{4}{|c|}{ Durbin-Watson value $=2.155$} \\
\hline \multicolumn{7}{|l|}{$\Delta \mathbf{R}^{2}=0.01 *$} \\
\hline \multicolumn{7}{|c|}{$\begin{array}{l}\text { Notes: }{ }^{*}: \mathrm{p}<0.05 \text { and }{ }^{* *}: \mathrm{p}<0.01 . \text { Moderator Effect: E-satisfaction }{ }^{*} \text { The Usage of The } \\
\text { Internet }\end{array}$} \\
\hline
\end{tabular}


According to the results of the hierarchical regression analysis, the first and second models were significant at the 95\% confidence level. In the first model without interaction term, e-satisfaction had a significant effect on e-loyalty, with an unstandardized beta coefficient of 0.655 ( $\mathrm{sig}=0.000$ ) however the Usage of The Internet had no significant effect on e-loyalty. The H1 hypothesis is supported. The total explained variance $\left(\mathrm{R}^{2}\right)$ of e-loyalty was $29.8 \%$. In the second model with the interaction term, e- satisfaction and moderator effect had a significant effect on eloyalty, with an unstandardized beta coefficient of 0.652 ( $\operatorname{sig}=0.000$ ) and 0.107 (sig=0.048). However, the usage of The Internet was insignificant on e-loyalty. $\mathrm{R}^{2}$ increased from $29.8 \%$ to $30.8 \% . \Delta \mathrm{R}^{2}=0.01$ increase was found to be significant at the $95 \%$ confidence level ( $\mathrm{p}$-value $=0.048$ ). The $\mathrm{H} 2$ hypothesis is supported. As seen in table 5 , the e-loyalty variable has increased as the Internet usage time increases. According to the results, the moderation hypothesis was accepted. The usage of the Internet moderate the relationship between e-satisfaction and e-loyalty. Visualisation of the results of the moderator analysis is shown in figure 5 .

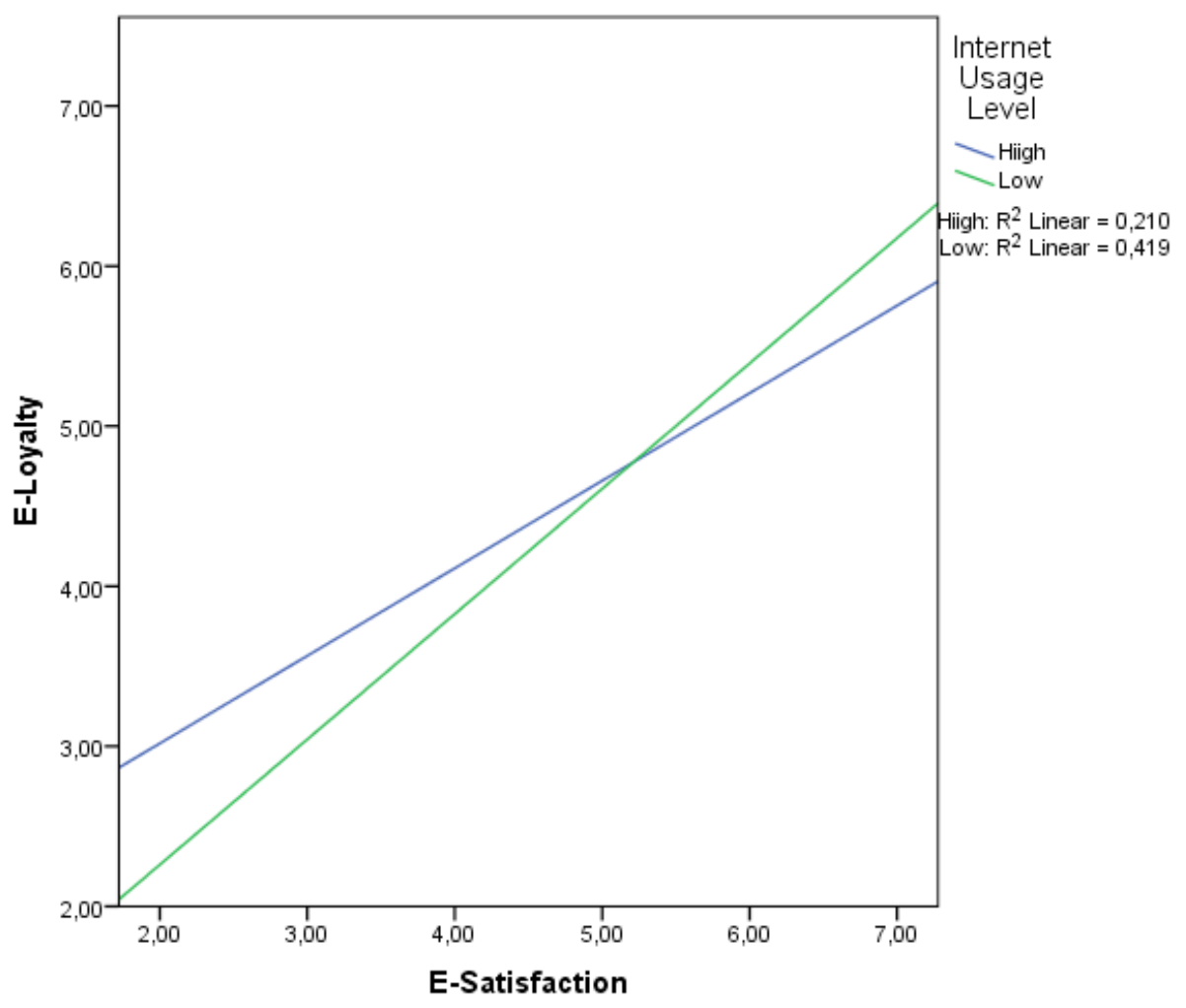

Figure 5: A visual representation of the usage of the Internet's moderator effect

According to this figure, the trend of low Internet usage level was found to be higher than that of high Internet usage level in terms of the relationship between esatisfaction and e-loyalty. In addition, the explained variance of the low Internet usage level $\mathrm{R}^{2}$ was 0.419 . This value was realized as 0.210 for high Internet usage level. The low the Internet usage level was more important in explaining the relationship between e-loyalty and e-satisfaction. It has been observed that the e-loyalty of consumers with the low Internet usage is higher than those with the high Internet usage level as the 
number of the Internet usage times increases. As a result, it can be said that the e-loyalty of consumers, who are at a very high the Internet usage level, has fallen.

\section{Discussion}

E-commerce is a sector that grows rapidly day by day. The use of the internet becomes more limitless and the consumers can access the goods/services information at the same time. Unlimited access to the Internet increases the website alternatives where consumers can buy products or services. Shaw and Lin (2006) say that as the use of the Internet increases, access to information increases and it becomes more difficult to achieve e-loyalty (p.385). Shin et al. (2016) say that as product alternatives for satisfied customers increase, they will not show much loyalty (p.4). Similarly, Chang and Wang (2011) say that product alternatives in the e-commerce sector will be easy to find and it will be difficult to establish long-term relationships with customers. It has also been found that satisfied customers are more likely to seek alternative websites and are more likely to change this website and that the relationship between consumer satisfaction and loyalty in the online environment are weaker than those in the offline environment. (Chang and Wang, 2011, p.335). E-satisfaction and e-loyalty would be lower than in offline medium, as product or service alternatives are only a few clicks away (Shankar, et al., 2003, p.153-154; Christodoulides and Michaelidou, 2010, p. 182). In addition, long-term Internet access allows websites to search for diversity. According to Berné et al. (2001), variety-seeking has a negative impact on e-loyalty. As a result, according to studies conducted in the literature, the presence of alternatives has a negative effect on e-loyalty. Considering the presence of the Internet in finding alternatives in the online environment, it can be said that the study we have done is supported by the literature.

As a result, the Internet usage level moderate the relationship between esatisfaction and e-loyalty. If the level of the Internet use is low, it becomes difficult to find an alternative, and as a result, e-loyalty is increasing. But nowadays, as the usage of the Internet is thought to become widespread and has even reached mobile phones, ecommerce companies need to provide extra services to make their customers loyal. Because as a result of the increased use of the internet, competition in the e-commerce sector increase. According to Porter (1998), there are three successful generic strategies that can be implemented in a competitive environment: differentiation, focus and overall cost leadership. Cost leadership strategy is a strategy that is implemented through tight cost alignment and minimization of costs. Differentiation is the separation from competitors by factors such as product and service offered, design, brand image, technology, customer service (Porter, 1998). Considering that e-commerce services provide cost advantages for each company, competition advantage can be achieved with differentiation strategy (Maurer et al., 2003). In other words, the differentiation strategy will enhance the concept of e-loyalty to the company. Many strategies have been proposed for differentiating websites from other sites. When the variables that increase e-loyalty are examined, it appears that one of these variables is e-trust (Oliveira et al., 2017; López-Miguens et al., 2017; Corbitt et al., 2003; Safa and Ismail, 2013; Nadeem et al, 2015; Ladhari and Leclerc, 2013; Forgas et al., 2012; Anderson and Srinivasan, 2003). E-trust is an important variable for e-commerce sites because consumers are shopping in a virtual environment. E-commerce companies can be created with e-trust using guarantees, website quality, perceived reputation related to web site, security, decrease of risk perceived by the consumer, minimization of shopping time (Oliveira et al., 2017; Toms and Taves, 2004; López-Miguens et al., 2017; Koh and Sundar, 2010). 
It is also possible that they gain consumer confidence as a result of their involvement in companies' social responsibility projects. The perceived risk can be reduced by increasing the consumer's utility of the product or service, or by facilitating processes related to the product or service and by offering a lower price to reduce the consumer's sacrifice (Chang and Wang, 2011). Another situation that is recommended is the branding of the website. Because the branding of the website can create brand awareness and image for the consumer. Thus branding offers a significant differentiation opportunity in the competitive environment. Another proposed situation is the use of social media channels for marketing communication efforts of websites. Companies use social media communication channels to establish a two-way communication with the consumer. So that trust between the consumer and the company can be provided and e-loyalty can be increased (Laroche et al., 2013; Nisar and Whitehead, 2016). As a result, the use of the social media communication channel adds accretion value to the e-commerce companies and is recommended for use in marketing communication.

\section{Conclusion}

Internet usage has seen significant increases. E-commerce companies that see the big cake have started to take part in the market. Because there are no barriers to entry in the e-commerce sector. This has led to a major rivalry in the e-commerce industry. The variable that provides it is the increase in internet usage. As the internet usage grows, disloyalty towards e-commerce companies has increased. E-commerce companies need to be different from their competitors in order to be able to reverse the situation. It is suggested to use the e-trust concept in the positioning of e-commerce companies, to establish two-way communication with consumers through social media communication channels, to start the branding process of the website and to take part in social responsibility projects.

Another result obtained from this study is the suggestion of effect size which has not been done before in e-commerce literature. The effect size value in this study was found to be 0.218867 . This value corresponds to the medium effect size proposed by Cohen. So the medium effect size can be used for statistical power analysis or to determine sample size in subsequent studies in e-commerce literature.

\section{Limitation and Suggestion for Future Research}

Since the random sampling is costly and time-consuming and there is no list of records related to the consumers, the convenience sampling method is used. Therefore, the study can not be generalized. But when similar studies are conducted in different geographies, the results will tend to generalize. 


\section{References}

Anderson, R. E., and Srinivasan, S. S. (2003), "E-satisfaction and e-loyalty: A Contingency Framework", Psychology and Marketing, Vol. 20 No.2, pp. 123128.

Baron, R. M., and Kenny, D. A. (1986), “The moderator-mediator variable distinction in social psychological research: Conceptual, strategic, and statistical considerations", Journal of personality and social psychology, Vol. 51 No. 6, pp. 1173-1182.

Bai, B., Law, R., and Wen, I. (2008), "The impact of website quality on customer satisfaction and purchase intentions: Evidence from Chinese online visitors", International journal of hospitality management, Vol. 27 No. 3, pp.391402.

Berné, C., Múgica, J. M., and Yagüe, M. J. (2001), “The effect of variety-seeking on customer retention in services", Journal of Retailing and Consumer Services, Vol. 8 No. 6, pp.335-345.

Blake, B. F., Neuendorf, K. A., and Valdiserri, C. M. (2003), "Innovativeness and variety of internet shopping", Internet Research, Vol. 13 No. 3, pp. 156-169.

Casidy, R., and Wymer, W. (2016), "A risk worth taking: Perceived risk as moderator of satisfaction, loyalty, and willingness-to-pay premium price", Journal of Retailing and Consumer Services, Vol. 32, pp. 189-197.

Chang, H. H., and Chen, S. W. (2008), “The impact of customer interface quality, satisfaction and switching costs on e-loyalty: Internet experience as a moderator", Computers in Human Behavior, Vol. 24 No. 6, pp. 2927-2944.

Chiou, J. S. (2004), “The antecedents of consumers' loyalty toward Internet service providers", Information and Management, Vol. 41 No. 6, pp. 685-695.

Christodoulides, G., and Michaelidou, N. (2010), "Shopping motives as antecedents of e-satisfaction and e-loyalty", Journal of Marketing Management, Vol. 27 No.1-2, pp. 181-197.

Cohen, J. (1988), "Statistical Power Analysis for the Behavioral Sciences (2nd ed.)", Hillsdale, NJ: Lawrence Erlbaum.

Cohen, J. (1962), "The statistical power of abnormal-social psychological research: a review", The Journal of Abnormal and Social Psychology, Vol. 65 No. 3, pp. 145153.

Corbitt, B. J., Thanasankit, T., and Yi, H. (2003), "Trust and e-commerce: a study of consumer perceptions", Electronic commerce research and applications, Vol. 2 No. 3, pp. 203-215.

Cyr, D., Kindra, G. S., and Dash, S. (2008), "Web site design, trust, satisfaction and eloyalty: the Indian experience", Online Information Review, Vol. 32 No. 6, pp. 773-790.

Çokluk, Ö., Şekercioğlu, G., and Büyüköztürk, Ş. (2010), "Sosyal bilimler için çok değişkenli istatistik: SPSS ve LISREL uygulamaları", Pegem Akademi. 
Dharmesti, M. D. D., and Nugroho, S. S. (2013), "The antecedents of online customer satisfaction and customer loyalty", Journal of Business and Retail Management Research, Vol. 7 No. 2.

E Porter, M. (1998), "Competitive strategy: Techniques for analyzing industries and competitors", Free press.

Evanschitzky, H., Iyer, G. R., Hesse, J., and Ahlert, D. (2004), "E-satisfaction: a reexamination", Journal of retailing, Vol. 80 No.3, pp. 239-247.

Forgas-Coll, S., Palau-Saumell, R., Sánchez-García, J., and Fandos-Roig, J. C. (2013), "Airline website loyalty formation and the moderating effects of gender and education", Service Business, Vol. 7 No.2, pp. 255-274.

Forgas, S., Palau, R., Sánchez, J., and Huertas-García, R. (2012), “Online drivers and offline influences related to loyalty to airline websites", Journal of Air Transport Management, Vol. 18 No. 1, pp. 43-46.

Hair Joseph F. Jr., Black William C., Babin Barry J. ve Anderson Rolph E., (2014), "Multivariate Data Analysis", Seventh Edition, Pearson New İnternational Edition

Han, H., Kim, Y., and Kim, E. K. (2011), "Cognitive, affective, conative, and action loyalty: Testing the impact of inertia", International Journal of Hospitality Management, Vol.30 No.4, pp. 1008-1019.

Harris, L. C., and Goode, M. M. (2004), "The four levels of loyalty and the pivotal role of trust: a study of online service Dynamics", Journal of retailing, Vol.80 No.2, pp. 139-158.

Hayes Andrew F., (2013), "Introduction to Mediation, Moderation and Conditional Process Analysis A Regression - Based Approach", The Guildford Press

Hayes, A. F., and Rockwood, N. J. (2016), "Regression-based statistical mediation and moderation analysis in clinical research: Observations, recommendations, and implementation", Behaviour Research and Therapy.

Hernández, B., Jiménez, J., and Martín, M. J. (2010), "Customer behavior in electronic commerce: The moderating effect of e-purchasing experience", Journal of business research, Vol. 63 No.9, pp. 964-971.

Hsin Chang, H., and Wang, H. W. (2011), "The moderating effect of customer perceived value on online shopping behaviour", Online Information Review, Vol. 35 No.3, pp. 333-359.

Keskin, B. (2012), "İstatistiksel Güç Analizi: Sosyal Bilimler Alanında Bir Uygulama", Akdeniz Üniversitesi Sosyal Bilimler Enstitüsü, İşletme Anabilim Dalı Yüksek Lisans Tezi, Antalya

Kemp, S. (2016), “Digital In 2016. We are social's compendium of global digital, social, and mobile data, trends, and statistics", We are social.

Kim, J. S., Kaye, J., and Wright, L. K. (2001), "Moderating and mediating effects in causal models", Issues in Mental Health Nursing, Vol. 22 No. 1, pp. 63-75.

Koh, Y. J., and Sundar, S. S. (2010), "Effects of specialization in computers, web sites, and web agents on e-commerce trust", International journal of human-computer studies, Vol. 68 No.12, pp. 899-912. 
Kraemer, H. C., Stice, E., Kazdin, A., Offord, D., and Kupfer, D. (2001), "How do risk factors work together? Mediators, moderators, and independent, overlapping, and proxy risk factors", American journal of psychiatry, Vol. 158 No. 6, pp. 848-856.

Ladhari, R., and Leclerc, A. (2013), "Building loyalty with online financial services customers: Is there a gender difference?", Journal of Retailing and Consumer Services, Vol. 20 No.6, pp. 560-569.

Lamont, M., and Jenkins, J. (2013), "Segmentation of cycling event participants: A twostep cluster method utilizing recreation specialization", Event Management, Vol. 17 No.4, pp. 391-407.

Laroche, M., Habibi, M. R., and Richard, M. O. (2013), "To be or not to be in social media: How brand loyalty is affected by social media?", International Journal of Information Management, Vol. 33 No. 1, pp. 76-82.

Lee, H., Choi, S. Y., and Kang, Y. S. (2009), "Formation of e-satisfaction and repurchase intention: Moderating roles of computer self-efficacy and computer anxiety", Expert Systems with Applications, Vol. 36 No.4, pp. 7848-7859.

Lindley, P., and Walker, S. N. (1993), "Theoretical and methodological differentiation of moderation and mediation”, Nursing Research, Vol. 42 No. 5, pp. 276-279.

López-Miguens, M. J., and Vázquez, E. G. (2017), “An integral model of e-loyalty from the consumer's perspective", Computers in Human Behavior, Vol. 72, pp. 397411.

Maurer, S. M., and Huberman, B. A. (2003), "Competitive dynamics of web sites", Journal of Economic Dynamics and Control, Vol. 27 No.11, pp. 21952206.

Michailidou, C., Maheras, P., Arseni-Papadimititriou, A., Kolyva-Machera, F., and Anagnostopoulou, C. (2009), "A study of weather types at Athens and Thessaloniki and their relationship to circulation types for the cold-wet period, part I: two-step cluster analysis", Theoretical and applied climatology, Vol. 97 No.1-2, pp. 163-177.

Nakip, Mahir, (2013), “Pazarlamada Araştırma Teknikleri”, 7. Baskı, Seçkin Yayınevi

Nysveen, H., and Pedersen, P. E. (2004), “An exploratory study of customers' perception of company web sites offering various interactive applications: moderating effects of customers' Internet experience”, Decision Support Systems, Vol. 37 No.1, pp. 137-150.

Malhotra, Naresh K., (2007), "Marketing Research An Applied Orientation”, 5. Edition, Prentice Hall.

Oliveira, T., Alhinho, M., Rita, P., and Dhillon, G. (2017), "Modelling and testing consumer trust dimensions in e-commerce", Computers in Human Behavior, Vol. 71, pp. 153-164.

Nadeem, W., Andreini, D., Salo, J., and Laukkanen, T. (2015), "Engaging consumers online through websites and social media: A gender study of Italian Generation Y clothing consumers", International Journal of Information Management, Vol. 35 No.4, pp. 432-442. 
Nisar, T. M., and Whitehead, C. (2016), "Brand interactions and social media: Enhancing user loyalty through social networking sites", Computers in Human Behavior, Vol. 62, pp. 743-753.

Rodgers, W., Negash, S., and Suk, K. (2005), "The moderating effect of online experience on the antecedents and consequences of online satisfaction", Psychology and Marketing, Vol. 22 No.4, pp. 313-331.

Safa, N. S., and Ismail, M. A. (2013), "A customer loyalty formation model in electronic commerce", Economic Modelling, Vol. 35, pp. 559-564.

Shankar, V., Smith, A. K., and Rangaswamy, A. (2003), "Customer satisfaction and loyalty in online and offline environments", International journal of research in marketing, Vol. 20 No.2, pp. 153-175.

Shaw, C. W., and Lin, S. W. (2006). "The antecedents of consumers' loyalty toward online stores", In 11th Annual Conference of Asia Pacific Decision Sciences Institute, Hong Kong, pp. 14-18.

Shin, S. I., Lee, K. Y., and Yang, S. B. (2016), "How do uncertainty reduction strategies influence social networking site fan page visiting? Examining the role of uncertainty reduction strategies, loyalty and satisfaction in continuous visiting behavior", Telematics and Informatics.

Toms, E. G., and Taves, A. R. (2004), "Measuring user perceptions of web site reputation", Information Processing and Management, Vol. 40 No.2, pp. 291-317.

Tsiptis, K., and Chorianopoulos, A. (2009), "Data mining techniques in CRM: Inside customer segmentation", Chichester: John Wiley and Sons.

United Nations Conference on Trade and Development, Information Economy Report, 2015

Varma Citrin, A., Sprott, D. E., Silverman, S. N., and Stem Jr, D. E. (2000), “Adoption of Internet shopping: the role of consumer innovativeness", Industrial management and data systems, Vol. 100 No.7, pp. 294-300.

Yilmaz, K. G., Gungordu, A., Ayci, A., \& Yumusak, T. (2016), E-Commerce Adoption as a Predictor of the Perceived Strategic Value of E-Commerce among ECommerce Adopter SMEs in Turkey, International Journal of Managerial Studies and Research (IJMSR), Vol:4:3, pp.35-43

$\mathrm{Wu}$, A. D., and Zumbo, B. D. (2008), "Understanding and using mediators and moderators", Social Indicators Research, Vol. 87 No.3, pp. 367-392. 